$\angle$ Research Square

\title{
Antineoplastic Effects of Erufosine on Small and Non-Small Lung Cancer Cells Through Induction of Apoptosis and Cell Cycle Arrest
}

Hüseyin Abdik ( $\square$ huseyin.abdik@izu.edu.tr)

Istanbul Sabahattin Zaim University: Istanbul Sabahattin Zaim Universitesi https://orcid.org/00000003-3756-0645

\section{Research Article}

Keywords: Lung cancer cells, Erufosine, Antineoplastic agent, Apoptosis, AKT

Posted Date: September 14th, 2021

DOI: https://doi.org/10.21203/rs.3.rs-868775/v1

License: (c) (1) This work is licensed under a Creative Commons Attribution 4.0 International License.

Read Full License 


\section{Abstract}

Background: Lung cancer (LC) is one of the most common types of cancer with a high mortality rate. Depending on molecular and histological properties, LC is divided into non-small-cell and small-cell lung cancer. Not only surgery but also radiotherapy, chemotherapy, or combination treatment are used for patients. However, the survival rate of LC is still very low. Erufosine (ErPC3) is a novel promising antineoplastic agent and inhibits the translocation of AKT to the plasma membrane by dephosphorylating AKT.

Methods and Results: In the current study, the cell-type dependent effects of ErPC3 on cell viability, apoptotic situation, cell cycle distribution, related gene expression, and migration capacities of A549 and DMS 114 were investigated. As results, ErPC3 exhibited cytotoxic and pro-apoptotic properties against both cells, while DMS 114 was more affected. ErPC3 accumulated the cells in G2/M phase and blocked cell cycle. Proliferation markers were downregulated, while pro-apoptotic markers were upregulated in ErPC3 treated cells. Besides, ErPC3 displayed anti-migratory effect on A549 and DMS 114 compared to the control group according to scratch assay.

Conclusion: These findings promise a treatment approach and drug development against LC. The obtained results from the recent study lead it necessary to carry out more detailed studies about ErPC3.

\section{Introduction}

Lung cancer is the second most commonly diagnosed cancer type $(11.4 \%)$ and has an $18 \%$ ratio among cancer-related death [1]. There are two different subtypes of lung cancer, non-small-cell lung cancer (NSCLC) and small-cell lung cancer (SCLC) according to their molecularly and histologically characteristic [2]. LC generally occurs as NSCLC type (85\%) and mostly derived from cigarette smoking [3]. However, $52 \%$ of lung cancer patients, especially women, are non-smokers according to recent reports [4]. In addition, genetic factors, aging, and environmental pollution may also cause the development of lung cancer [5-7]. SCLC is a more lethal type due to its aggressiveness and poor prognosis [8]. Most lung cancer patients cannot have surgery; they only take radiotherapy, chemotherapy, or combination treatment. These limited opportunities result in a short survival rate of five years [9]. In addition, LC diagnosis is delayed due to insensible symptoms and changes in epidemiology [10].

Variable processes activate apoptosis; inhibiting molecules such as Bcl-xl, Bcl-2, and the IAP family of proteins or promoting molecules such as Bak, Bax, and caspases have critical roles in apoptosis [11]. These pathways are often targets of cancer treatments. Besides, PI3K/AKT/mTOR pathway is upregulated in many human cancers, including lung cancer, hence, it has been recognized as a promising target, which could offer therapeutic potential through small molecule-based therapies [12]. This pathway contributes to tumorigenesis, tumor progression and drug resistance [13]. It is possible that AKT is a critical point and play role in lung cancer development due to serving active Akt in lung cancer precursors 
[14]. In NSCLC, active AKT frequently is found and possibly related to higher progression and lymph node metastasis [15-17]. Therefore high AKT activity decreases the survival rate of patients [16]. AKT activation may derive from mutations, increased expressions of AKT isoforms (AKT1, AKT2 or AKT3) and their upstream regulators, and decreased negative regulators $[17,18]$. Moreover, the expression level of AKT also relates to the chemoresistance of SCLC. The recurrence and developing drug-resistant contribute to the poor prognosis in SCLC patients [19].

Alkylphosphosphocholine (APC) differs from traditional chemotherapeutics, due to its interaction with cell membrane rather than DNA [20]. APCs are antineoplastic compounds with anti-apoptotic and cytotoxic activities [21]. Erufosine (erucylphospho-N,N,N-trimethylpropanolamine, ErPC3) is a novel membare-targeted agent and inhibits the translocation of AKT to the plasma membrane by dephosphorylating AKT on Ser473 protein [22,23]. Antineoplastic effects of ErPC3 on various cancer types such as prostate cancer [23], leukemia [24], colorectal cancer [25], breast cancer [26], glioblastoma [27] and oral squamous carcinoma [28] have been proven. Besides, ErPC3 displayed pro-apoptotic activity via caspase-dependent signaling [29].

In the current study, the antineoplastic activity of ErPC3 on Human non-small cell lung cancer (NSCLC) cell line, A549 and small cell lung cancer (SCLC) cell lines, DMS 114 were evaluated. The comparative study was held to investigate the cell-type dependent effect of ErPC3 on cell viability, apoptotic situation, cell cycle distribution, related gene expression, and migration capacities of both cells.

\section{Materials And Methods}

\section{Cell Lines and Reagents}

Human non-small cell lung cancer (NSCLC) cell line, A549 and small cell lung cancer (SCLC) cell lines, DMS 114 were used for the current study. The cells were cultured in Dulbecco's Modified Eagle Medium with $4.5 \mathrm{~g} / \mathrm{L}$ D-glucose (DMEM, Invitrogen, Gibco, UK) containing 10\% fetal bovine serum (FBS, Invitrogen, Gibco, UK) and 1\% of penicillin/streptomycin/amphotericin (PSA, Invitrogen, Gibco, UK) and incubated at $37^{\circ} \mathrm{C}$ in a $5 \% \mathrm{CO}_{2}$ humidified incubator. When the cells reach enough confluency $(\sim 80 \%)$, they were passaged by using $0.25 \%$ trypsin/EDTA (\#25200-056, Invitrogen, Gibco, UK). Prof. H. Eibl from Max Planck-Institute of Biophysical Chemistry, Göttingen, Germany provided Erufosine (ErPC3). ErPC3 was prepared at a concentration of $20 \mathrm{mmol} / \mathrm{L}$ in saline and kept at $4^{\circ} \mathrm{C}$ for long-term storage.

\section{Cell Viability Assay}

To determine the effects of ErPC3 on the cell viability of A549 and DMS 114, MTS assay (3-(4,5-di-methylthiazol-2-yl)-5-(3-carboxy-methoxyphenyl)-2-(4-sulfo-phenyl)-2H-tetrazolium (\#G3582,CellTiter96 AqueousOne Solution; Promega, Southampton, UK)) was performed for $48 \mathrm{~h}$. The cells were seeded onto 96-well plate at a concentration of $5^{\star} 10^{3}$ cells/well. Next day, the cells were exposed to different concentrations of ErPC3 such as $6.25,12.5,25,50$, and $100 \mu \mathrm{M} .24$ and 48h after administrations, MTS reagent was added onto the wells and incubated at $37^{\circ} \mathrm{C}$ in a $5 \% \mathrm{CO} 2$ humidified incubator for $1 \mathrm{~h}$. The 
plates were measured at 495nm by ELISA microplate reader (Biotek, Winooski, VT). $25 \mu \mathrm{M}$ ErPC3 was selected for subsequent experiments according to MTS results.

\section{Annexin V \& Dead Cell Assay}

Apoptotic situations of A549 and DMS 114 under $25 \mu \mathrm{M}$ ErPC3 administration were evaluated by Muse ${ }^{\circledR}$ Annexin V \& Dead Cell Kit (Merck Millipore, USA and Canada). The cells were seeded onto 6-well plate at a concentration of $0.1 * 10^{6}$ cells/well. Next day, the cells were exposed to growth media with and without 25 $\mu \mathrm{M}$ ErPC3. 48h after administration, the cells were collected from the wells and treated with the kit according to the manufacturer's instructions and analyzed with Muse ${ }^{\circledR}$ Cell Analyzer (Merck Millipore, USA and Canada).

\section{Cell Cycle Assay}

Muse® Cell Cycle Kit (Merck Millipore USA and Canada) was used for evaluating the cell cycle distribution of A549 and DMS 114 under $25 \mu \mathrm{M}$ ErPC3 administration. The cells were cultured into 6-well plate at a concentration of $0.1 * 10^{6}$ cells/well. After day, normal growth media with and without $25 \mu \mathrm{M}$ ErPC3 was added on the wells. 48h later, the cells were centrifuged and fixed with $70 \%$ cold-ethanol for $2 \mathrm{~h}$. The kit was applied to the groups according to the manufacturer's instructions and analyzed with Muse® Cell Analyzer.

\section{Quantative Polimerase Chain Reaction (qPCR)}

To evaluate the expression levels of apoptosis and proliferation-related genes of A549 and DMS 114 under $25 \mu \mathrm{M}$ ErPC3 administration, qPCR analysis was carried out. AKT, BAX, BCL-2, CAS3, and CAS7 were selected as marker genes. The cells were seeded onto 6 -well plate at a concentration of $0.1 * 10^{6}$ cells/well. Next day, the cells were administered with growth media with and without $25 \mu \mathrm{M}$ ErPC3. $48 \mathrm{~h}$ after administration, the pellets were obtained from the wells, and total RNA isolation were done by the kit (Roche, USA) according to the manufacturer's instructions. Later, isolated RNAs were used as samples in cDNA synthesis reaction by Transcriptor High Fidelity cDNA Synthesis Kit (Roche, USA) according to the manufacturer's instructions. Finally, SYBR Green (Thermo-Fischer, USA), gene specific primers and synthesized cDNA were mixed for qPCR analysis. The reaction was performed by running iCycler RT-PCR system (CFX Real Time System; Bio-Rad, Singapore).

\section{Western Blot Analysis}

The expressions of target proteins -Akt and p-Akt- of the $25 \mu \mathrm{M}$ ErPC3 treated A549 and DMS 114 were evaluated by western blot analysis. The cells were cultured onto 6-well plate at a concentration of $0.1 * 10^{6}$

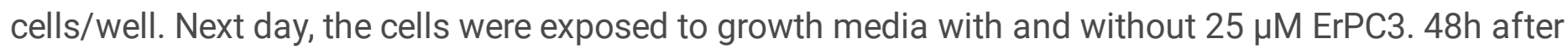
administration, the cell pellets were collected and total proteins were isolated by using Radio immunoprecipitation assay (RIPA) buffer (\#sc-24948, Santa Cruz, USA). To calculate the protein concentrations, Bicinchoninic acid (BCA) assay (\#23227, Pierce, Rockford, USA) was performed. For electrophoresis, Any kDTM Mini-PROTEAN®TGXTM precast gels (\#456-9033, Biorad, USA) was used. After the running step, the gels were transferred to nitrocellulose membranes (122 - 0115, Biorad, 
Germany). The blocking step was carried out with $5 \%$ nonfat dry milk powder (36-6404, Biorad, USA). The membranes incubated with primary antibodies of Akt (\#ab9272, Abcam Cambridge, MA, USA) and p-Akt (\#ab9271, Abcam Cambridge, MA, USA), at $4^{\circ} \mathrm{C}$ over-night. Next day, the membranes were washed with $1 \times$ Tris-buffered saline and Tween-20 solution (TBS-T) and incubated with anti-rabbit (\#7074, Cell

Signaling, Beverly, MA, USA) secondary antibodies at RT for $1 \mathrm{~h}$. Finally, the membranes were photographed with a ChemiDoc MP imaging system (BioRad, USA) by using Enhanced chemiluminescence (ECL) substrate (\# 1705060, BioRad, USA). The bands were normalized by using the expression of GAPDH (\#8884, Cell Signaling, Beverly, MA, USA).

\section{Scratch Assay}

Scratch assay was carried out as a model experiment to determine the migration capacities of A549 and DMS 114 under $25 \mu \mathrm{M}$ ErPC3 administration. They were seeded onto 6-well plate at a concentration of $0.1 * 10^{6}$ cells/well. When the cells reached to $\sim 100 \%$ confluency, scratch model was formed by using a sterile $200 \mu \mathrm{L}$ pipette. Then, normal growth media with and without $25 \mu \mathrm{M}$ ErPC3 was added on the wells. The wells were photographed by the Zeiss PrimoVert light microscope with an AxioCam ERc5s camera (Carl Zeiss Microscopy, LLC, Thornwood, NY, USA) at 0 and 24h and closure area rates were calculated by five randomly selected points using Zen 2011 software.

\section{Statistical Analysis}

One-way analysis of variance (ANOVA) followed by Tukey's post hoc test were chosen for statistical analysis. GraphPad Prism (version 7.00; GraphPad Software, Inc., San Diego, CA, USA) were used for all analysis and ${ }^{*} p<0.05$ was accepted statistically significant results.

\section{Results}

The highest doses of ErPC3 significantly decreased the cell viability of lung cancer cell lines but displayed more effectiveness on DMS 114 compared to A549

A549 and DMS 114 were exposed to different concentrations of ErPC3 to detect the effects of ErPC3 on the cell viability of the cells for $48 \mathrm{~h}$. After $24 \mathrm{~h}$ administration, the highest doses of ErPC3 $(25,50$, and 100 $\mu \mathrm{M})$ significantly decreased the cell viability of both cells compared to the control group (Fig. 1). Interestingly, 6.25 and $12.5 \mu \mathrm{M}$ ErPC3 significantly increased the cell viability of DMS 114 . The next day, ErPC3 caused significant differences except 6.25 and $12.5 \mu \mathrm{M}$ compared to the control group. While 25 $\mu \mathrm{M}$ ErPC3 decreased the cell viability of A549 to $79.34 \pm 12.79 \%$, the cell viability of DMS 114 was decreased to $42.13 \pm 8.9 \%$ at the end of the $48 \mathrm{~h}$. To evaluate the cell type-dependent effects of ErPC3 on the non-small cell lung cancer (NSCLC) cell line and small cell lung cancer (SCLC) cell lines, $25 \mu \mathrm{M}$ ErPC3 was selected for both cells in subsequent experiments.

\section{Apoptotic cell rates of the lung cancer cell lines were increased after ErPC3 administration}


Annexin V \& Dead Cell Assay was done to evaluate apoptotic situation of A549 and DMS 114 when they were exposed to $25 \mu \mathrm{M}$ ErPC3 for $48 \mathrm{~h}$. There was a significant difference between control and treated groups in the aspect of live cell and apoptotic cell ratios in both cells (Fig. 2). In A549, ErPC3 caused $25.10 \%$ apoptotic cell ratio while $9.35 \%$ was measured in the control group. Besides, higher apoptotic ratio (61.40\%) was showed in ErPC3 treated-DMS 114.

ErPC3 increased cell ratio in sub G0/G1 and caused accumulation of A549 and DMS 114 in G2/M phase

Cell cycle analysis was carried out to detect the cell cycle distribution of A549 and DMS 114 under $25 \mu \mathrm{M}$ ErPC3 treatment for $48 \mathrm{~h}$. The cells displayed different distributions compared to the control group. Both cells gave higher apoptotic pick in Sub G0/G1 compared to the control groups. Besides, the cell ratios of ErPC3-treated A549 and DMS 114 in G2/M phase were significantly increased compared to the control group (Fig. 3).

ErPC3 administration caused overexpression in apoptosis-related genes and downregulation in the proliferation-related gene, BCL-2, for both cells. Besides, ErPC3 did not change gene and protein expression levels of AKT, while protein levels of p-Akt was down expressed compared to the control group

To observed the levels of apoptosis and proliferation-related genes in A549 and DMS 114 under $25 \mu \mathrm{M}$ ErPC3 treatment for 48h, qPCR analysis was performed. In A549, the expressions of AKT and BCL-2, proliferation-related genes, were evaluated. AKT expression was not changed, while BCL-2 ( 0.5) was significantly down expressed under the administration. Besides, ErPC3 significantly increased expressions of BAX, CASP3, and CASP7, which were apoptosis-related genes, to $3.11,3.18$, and 1.93 folds compared to the control group, respectively. Similarly, ErPC3 did not cause any difference in AKT levels. However, it significantly decreased the expressions of BCL-2 to 0.21 in DMS 114, while BAX, CASP3, and CASP7 were significantly increased to $3.46,1.27$, and 1.66 folds compared to the control group.

According to western blot analysis, the protein expression level of Akt in both $25 \mu \mathrm{M}$ ErPC3 treated cells was not changed compared to the control group. However, active form of Akt, p-Akt, was down expressed in A549 and DMS 114 to 0.48 and 0.35 folds compared to the control group, respectively.

\section{The migration capacities of both cells were significantly decreased under ErPC3 administration in scratch assay}

To evaluate the effects of ErPC3 on the migration capacities of A549 and DMS 114, scratch assay was done. According to the analysis of taken photos at 0 and 24h, the wound closure rate of A549 under the administration was $\sim 47 \%$, while 80\% was measured in the control group (Fig. 5A). For DMS 114, 25\% closure rate was observed in $25 \mathrm{uM} \mathrm{ErPC3}$ treated group at the end of the $24 \mathrm{~h}$, while closure rate in the control group was 54\% (Fig. 5B).

\section{Discussion}


According to the 2020 report, new Lung cancer (LC) cases and death rates were estimated as 2.2 million and 1.8 million, respectively [1]. Despite understanding the reasons for the development of LC such as smoking, genetics, and immune system's effects and the discovery of new treatment options, lung cancer still has a critical level for cancer-related death [30]. LC has been increasing since 2011 in developing countries in parallel with tobacco smoking [31]. Conversely, lower tobacco smoking rates decrease the incidence and mortality of lung cancer in the United States. Not only tobacco smoking but also gender, age, race, geography, and socioeconomic status also influence LC development and outcomes [30]. As small cell lung cancer (SCLC) and non-small-cell lung cancer (NSCLC), primary lung cancer is histologically and molecularly divided into different groups. $85 \%$ of all cases are NSCLC consisting of subtypes such as adenocarcinoma, squamous cell carcinoma, and large cell carcinoma [32].

LC, especially SCLC, has high aggressiveness and chemoresistant among all malignant tumors. Tumor cell heterogeneity and cancer stem cells contributed to these properties [33, 34]. Classically, surgery and chemotherapy are the most preferred treatment options, however, the survival rate of lung cancer is very low with 5-year [35]. Many other factors also influence the poor prognosis of lung cancer such as age, sex, lung function, clinical and pathological stage, body constitution, comorbidity, and optimal treatment [36]. Depends on the high migratory capacities of lung cancer, many patients cannot even have an operation and chemotherapeutic agents alone are used in therapy [37]. The discovery of better treatment options for both lung cancer types is urgently needed.

$25 \mu \mathrm{M}$ and higher doses of ErPC3 significantly decreased the cell viability rate of both cells compared to the control group at 24 and 48h. Interestingly, $25 \mu \mathrm{M}$ ErPC3 caused different effects between the cells at 48h. While the cell viability of A549 was decreased to 81\%, DMS 114 was decreased to $~ 42 \%$. DMS 114 is a type of SCLC, the most aggressive and chemoresistant subtype of LC [38]. However, $25 \mu \mathrm{M} \mathrm{ErPC3}$ displayed more toxicity on DMS 114 than A549. Besides, apoptotic situations of A549 and DMS 114 under $25 \mu \mathrm{M}$ ErPC3 administration overlapped with cell viability analysis. Previous studies have shown that ErPC3 displayed pro-apoptotic effects on various cancer types, including prostate cancer [39], acute myeloid leukemia [24, 40], chronic lymphocytic leukemia [40], acute T-lymphocytic leukemia [41], oral squamous carcinoma [28], human glioblastoma [27]. According to cell cycle analysis, ErPC3 arrested A549 and DMS 114 in G2/M phase. Besides, higher apoptotic pick was measured in Sub G0/G1 phase for both ErPC3-treated cells compared to the control group. In previous studies, ErPC3 displayed proapoptotic effects on different cancer cells through blocking pass from G2/M to G0/G1 phase [42, 43].

Not only lung cancer subtypes but also other cancer types such as breast cancer [44], melanoma [45], gastric carcinoma [46] and hematologic malignancies [47] exhibit chemoresistant activity by using particular pathways which are responsible for many cellular processes. For instance, the PI3K/Akt/mTOR pathway is play an important role in the resistant mechanism. This pathway is a favorable goal for the development of anti-cancer agents [48]. AKT expressions of the A549 and DMS 114 under the $25 \mu \mathrm{M}$ ErPC3 was not changed while active form of Akt (p-Akt) was downregulated compared to the control group. ErPC3 inhibits the translocation of AKT to the plasma membrane by dephosphorylating AKT on Ser473 protein [22, 23]. Besides, BCL-2 expression, an anti-apoptotic marker [39], was decreased in $25 \mu \mathrm{M}$ 
ErPC3-treated group for both cells. The typical target in cancer therapy is the activation of the cascade of proteolytic enzymes, caspases. Moreover, Bax activation is also a marker of cell death [49]. When A549 and DMS 114 were treated with ErPC3, expressions of Caspase 3 and 7 and Bax were significantly decreased compared to the control group. Cancer cells spread away from their primary site, and migration capacities of the cells are related to aggressiveness. The anti-migratory effects of anti-carcinogenic drugs indicate antineoplastic activity. In the current study, migration capacities of $25 \mu \mathrm{M}$ ErPC3 treated A549 and DMS 114 were significantly decreased compared to the control group. Similar results were also reported by the previous studies in different cell types $[39,50]$.

Overall, LC incidence and mortality rate is increase day by day worldwide. There are two different main types NSCLC and SCLC, with different characteristics. Used treatment options including surgery, radiotherapy, chemotherapy, or combination are not fully successful. ErPC3 has a novel promising agent, according to the current study. The cell-type dependent antineoplastic activity of the ErPC3 on the A549 and DMS 114 has been demonstrated. In further studies, in vivo LC model should be conducted to support the anti-cancer effects of ErPC3 have on an organism.

\section{Declarations}

\section{Acknowledgement}

This study was funded by Yeditepe University. The author thanks Prof. Fikrettin Şahin for his support and Prof. Ferda Kaleagasıoglu and Prof. Martin Berger for providing the agent.

\section{Funding}

Not applicable

\section{Author information}

\section{Affiliations-Corresponding author}

Hüseyin Abdik

Department of Molecular Biology and Genetics, Faculty of Engineering and Natural Sciences, Istanbul Sabahattin Zaim University, Istanbul, Turkey.

\section{Author Contributions}

Hüseyin Abdik: Investigation, Methodology, Validation, Visualization, Writing - original draft.

\section{Ethics declarations}

\section{Conflicts of interest}

The authors declare no conflicts of interest. 


\section{Ethical approval}

This study does not require ethical statement.

\section{Consent to participate}

Not applicable

\section{Consent for publication}

Not applicable

\section{References}

1. Sung H, Ferlay J, Siegel RL, et al (2021) Global cancer statistics 2020: GLOBOCAN estimates of incidence and mortality worldwide for 36 cancers in 185 countries. CA Cancer J Clin 71:209-249

2. Travis WD, Brambilla E, Burke AP, et al (2015) Introduction to the 2015 World Health Organization classification of tumors of the lung, pleura, thymus, and heart. J Thorac Oncol 10:1240-1242

3. Hecht SS (2003) Tobacco carcinogens, their biomarkers and tobacco-induced cancer. Nat Rev Cancer $3: 733-744$

4. Yu C-J (2018) Letter from Taiwan. Respirology 23:535-537

5. Ji X, Bossé Y, Landi MT, et al (2018) Identification of susceptibility pathways for the role of chromosome 15q25. 1 in modifying lung cancer risk. Nat Commun 9:1-15

6. Lee PN, Forey BA, Coombs KJ, et al (2016) Time trends in never smokers in the relative frequency of the different histological types of lung cancer, in particular adenocarcinoma. Regul Toxicol Pharmacol 74:12-22

7. Eckel SP, Cockburn M, Shu Y-H, et al (2016) Air pollution affects lung cancer survival. Thorax 71:891898

8. Gelsomino F, Rossi G, Tiseo M (2014) MET and small-cell lung cancer. Cancers (Basel) 6:2100-2115

9. Yan Y, Su C, Hang M, et al (2017) Recombinant Newcastle disease virus rL-RVG enhances the apoptosis and inhibits the migration of $\mathrm{A} 549$ lung adenocarcinoma cells via regulating alpha 7 nicotinic acetylcholine receptors in vitro. Virol J 14:190. https://doi.org/10.1186/s12985-017-0852-z

10. McLean AEB, Barnes DJ, Troy LK (2018) Diagnosing Lung Cancer: The Complexities of Obtaining a Tissue Diagnosis in the Era of Minimally Invasive and Personalised Medicine. J Clin Med 7:. https://doi.org/10.3390/jcm7070163 
11. Deveraux QL, Schendel SL, Reed JC (2001) Antiapoptotic proteins. The bcl-2 and inhibitor of apoptosis protein families. Cardiol Clin 19:57-74. https://doi.org/10.1016/s0733-8651(05)70195-8

12. Cheng H, Shcherba M, Pendurti G, et al (2014) Targeting the PI3K/AKT/mTOR pathway: potential for lung cancer treatment. Lung Cancer Manag 3:67-75

13. Vivanco I, Sawyers CL (2002) The phosphatidylinositol 3-kinase-AKT pathway in human cancer. Nat Rev Cancer 2:489-501

14. Tsao AS, McDonnell T, Lam S, et al (2003) Increased phospho-AKT (Ser473) expression in bronchial dysplasia: implications for lung cancer prevention studies. Cancer Epidemiol Prev Biomarkers 12:660664

15. Balsara BR, Pei J, Mitsuuchi Y, et al (2004) Frequent activation of AKT in non-small cell lung carcinomas and preneoplastic bronchial lesions. Carcinogenesis 25:2053-2059.

https://doi.org/10.1093/carcin/bgh226

16. Tang J-M, He Q-Y, Guo R-X, Chang X-J (2006) Phosphorylated Akt overexpression and loss of PTEN expression in non-small cell lung cancer confers poor prognosis. Lung Cancer 51:181-191. https://doi.org/10.1016/j.lungcan.2005.10.003

17. Scrima M, De Marco C, Fabiani F, et al (2012) Signaling networks associated with AKT activation in non-small cell lung cancer (NSCLC): new insights on the role of phosphatydil-inositol-3 kinase. PLoS One 7:e30427. https://doi.org/10.1371/journal.pone.0030427

18. Papadimitrakopoulou V, Adjei AA (2006) The Akt/mTOR and mitogen-activated protein kinase pathways in lung cancer therapy. J Thorac Oncol Off Publ Int Assoc Study Lung Cancer 1:749-751

19. Tripathi SC, Fahrmann JF, Celiktas M, et al (2017) MCAM mediates chemoresistance in small-cell lung cancer via the PI3K/AKT/SOX2 signaling pathway. Cancer Res 77:4414-4425

20. Chometon G, Cappuccini F, Raducanu A, et al (2014) The membrane-targeted alkylphosphocholine erufosine interferes with survival signals from the extracellular matrix. Anti-Cancer Agents Med Chem (Formerly Curr Med Chem Agents) 14:578-591

21. van Blitterswijk WJ, Verheij M (2013) Anticancer mechanisms and clinical application of alkylphospholipids. Biochim Biophys Acta (BBA)-Molecular Cell Biol Lipids 1831:663-674

22. Yosifov DY, Konstantinov SM, Berger MR, Erucylphospho-N N (2009) N-trimethylpropylammonium shows substantial cytotoxicity in multiple myeloma cells. Ann N Y Acad Sci 1171:350

23. Rudner J, Ruiner C-E, Handrick R, et al (2010) The Akt-inhibitor Erufosine induces apoptotic cell death in prostate cancer cells and increases the short term effects of ionizing radiation. Radiat Oncol 5:1-12 
24. Martelli AM, Papa V, Tazzari PL, et al (2010) Erucylphosphohomocholine, the first intravenously applicable alkylphosphocholine, is cytotoxic to acute myelogenous leukemia cells through JNK-and PP2A-dependent mechanisms. Leukemia 24:687-698

25. Kaleagasioglu F, Berger MR (2014) Differential effects of erufosine on proliferation, wound healing and apoptosis in colorectal cancer cell lines. Oncol Rep 31:1407-1416

26. Dineva IK, Zaharieva MM, Konstantinov SM, et al (2012) Erufosine suppresses breast cancer in vitro and in vivo for its activity on PI3K, c-Raf and Akt proteins. J Cancer Res Clin Oncol 138:1909-1917

27. Veenman L, Alten J, Linnemannstöns K, et al (2010) Potential involvement of F 0 F 1-ATP (synth) ase and reactive oxygen species in apoptosis induction by the antineoplastic agent erucylphosphohomocholine in glioblastoma cell lines. Apoptosis 15:753-768

28. Ansari SS, Sharma AK, Soni H, et al (2018) Induction of ER and mitochondrial stress by the alkylphosphocholine erufosine in oral squamous cell carcinoma cells. Cell Death Dis 9:1-15

29. Königs SK, Pallasch CP, Lindner LH, et al (2010) Erufosine, a novel alkylphosphocholine, induces apoptosis in CLL through a caspase-dependent pathway. Leuk Res 34:1064-1069

30. Bade BC, Dela Cruz CS (2020) Lung Cancer 2020: Epidemiology, Etiology, and Prevention. Clin Chest Med 41:1-24. https://doi.org/https://doi.org/10.1016/j.ccm.2019.10.001

31. Ng M, Freeman MK, Fleming TD, et al (2014) Smoking prevalence and cigarette consumption in 187 countries, 1980-2012. Jama 311:183-192

32. Subramanian J, Regenbogen T, Nagaraj G, et al (2013) Review of ongoing clinical trials in non-smallcell lung cancer: a status report for 2012 from the ClinicalTrials.gov Web site. J Thorac Oncol Off Publ Int Assoc Study Lung Cancer 8:860-865. https://doi.org/10.1097/JT0.0b013e318287c562

33. Semenova E, Böttger F, Song JY, et al (2018) PO-338 Tumour heterogeneity underlies differential cisplatin sensitivity in mouse models of SCLC. ESMO Open 3:A360-A361

34. Sarvi S, Mackinnon AC, Avlonitis N, et al (2014) CD133 + cancer stem-like cells in small cell lung cancer are highly tumorigenic and chemoresistant but sensitive to a novel neuropeptide antagonist. Cancer Res 74:1554-1565

35. Thomas A, Chen Y, Yu T, et al (2015) Trends and Characteristics of Young Non-Small Cell Lung Cancer Patients in the United States. Front Oncol 5:113. https://doi.org/10.3389/fonc.2015.00113

36. Dela Cruz CS, Tanoue LT, Matthay RA (2011) Lung cancer: epidemiology, etiology, and prevention. Clin Chest Med 32:605-644. https://doi.org/10.1016/j.ccm.2011.09.001 
37. Islam KMM, Jiang X, Anggondowati T, et al (2015) Comorbidity and Survival in Lung Cancer Patients. Cancer Epidemiol biomarkers Prev a Publ Am Assoc Cancer Res cosponsored by Am Soc Prev Oncol 24:1079-1085. https://doi.org/10.1158/1055-9965.EPI-15-0036

38. Sabari JK, Lok BH, Laird JH, et al (2017) Unravelling the biology of SCLC: implications for therapy. Nat Rev Clin Oncol 14:549-561

39. Avsar Abdik E, Kaleagasioglu F, Abdik H, et al (2019) ABT-737 and erufosine combination against castration-resistant prostate cancer: a promising but cell-type specific response associated with the modulation of anti-apoptotic signaling. Anticancer Drugs 30:383-393

40. Fiegl M, Lindner LH, Juergens $\mathrm{M}$, et al (2008) Erufosine, a novel alkylphosphocholine, in acute myeloid leukemia: single activity and combination with other antileukemic drugs. Cancer Chemother Pharmacol 62:321-329

41. Lemeshko V V, Kugler W (2007) Synergistic inhibition of mitochondrial respiration by anticancer agent erucylphosphohomocholine and cyclosporin A. J Biol Chem 282:37303-37307

42. Kapoor V, Zaharieva MM, Das SN, Berger MR (2012) Erufosine simultaneously induces apoptosis and autophagy by modulating the Akt-mTOR signaling pathway in oral squamous cell carcinoma. Cancer Lett 319:39-48. https://doi.org/https://doi.org/10.1016/j.canlet.2011.12.032

43. Pervaiz A, Akhtar MS, Mahmood S, et al (2018) Molecular basis of cell cycle arrest induced by erufosine in metastatic breast cancer cells

44. Steelman LS, Navolanic PM, Sokolosky ML, et al (2008) Suppression of PTEN function increases breast cancer chemotherapeutic drug resistance while conferring sensitivity to mTOR inhibitors.

Oncogene 27:4086-4095

45. Sinnberg T, Lasithiotakis K, Niessner H, et al (2009) Inhibition of PI3K-AKT-mTOR Signaling Sensitizes Melanoma Cells to Cisplatin and Temozolomide. J Invest Dermatol 129:1500-1515. https://doi.org/https://doi.org/10.1038/jid.2008.379

46. Matsuoka T, Yashiro M (2014) The Role of PI3K/Akt/mTOR Signaling in Gastric Carcinoma. Cancers (Basel) 6:1441-1463. https://doi.org/10.3390/cancers6031441

47. Barrett D, Brown VI, Grupp SA, Teachey DT (2012) Targeting the PI3K/AKT/mTOR signaling axis in children with hematologic malignancies. Pediatr Drugs 14:299-316

48. Li X, Li C, Guo C, et al (2021) PI3K/Akt/mTOR signaling orchestrates the phenotypic transition and chemoresistance of small cell lung cancer. J Genet Genomics. https://doi.org/https://doi.org/10.1016/j.jgg.2021.04.001 
49. Fulda S, Debatin K-M (2013) Caspase activation in cancer therapy. In: Madame Curie Bioscience Database [Internet]. Landes Bioscience

50. Ansari SS, Akgün N, Berger MR (2017) Erufosine increases RhoB expression in oral squamous carcinoma cells independent of its tumor suppressive mode of action - a short report. Cell Oncol 40:8996. https://doi.org/10.1007/s13402-016-0302-8

\section{Figures}




\section{A549}

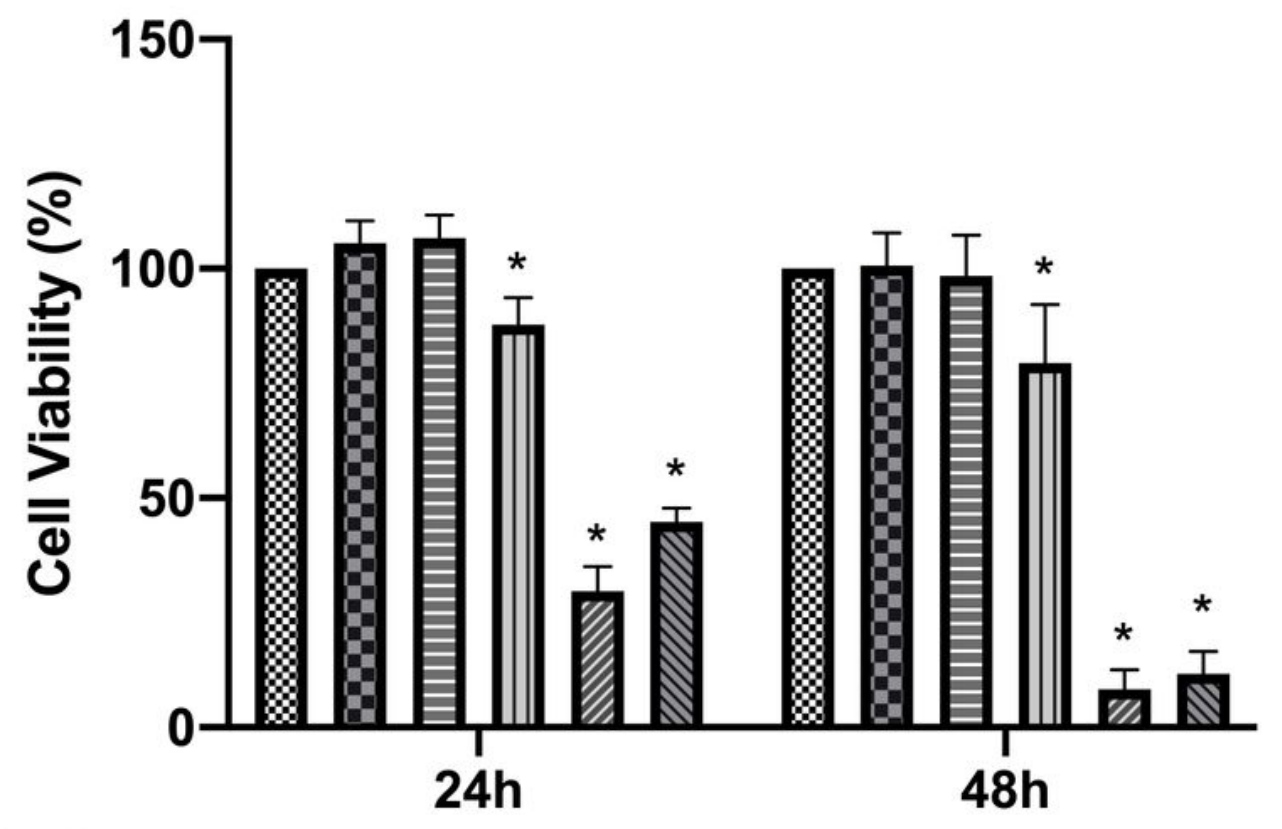

m Control

․․ $6.25 \mu \mathrm{M}$ ErPC3

曰 $12.5 \mu \mathrm{M}$ ErPC3

血 $25 \mu \mathrm{M}$ ErPC3

III $50 \mu \mathrm{M}$ ErPC3

ه $100 \mu \mathrm{M}$ ErPC3

\section{DMS 114}

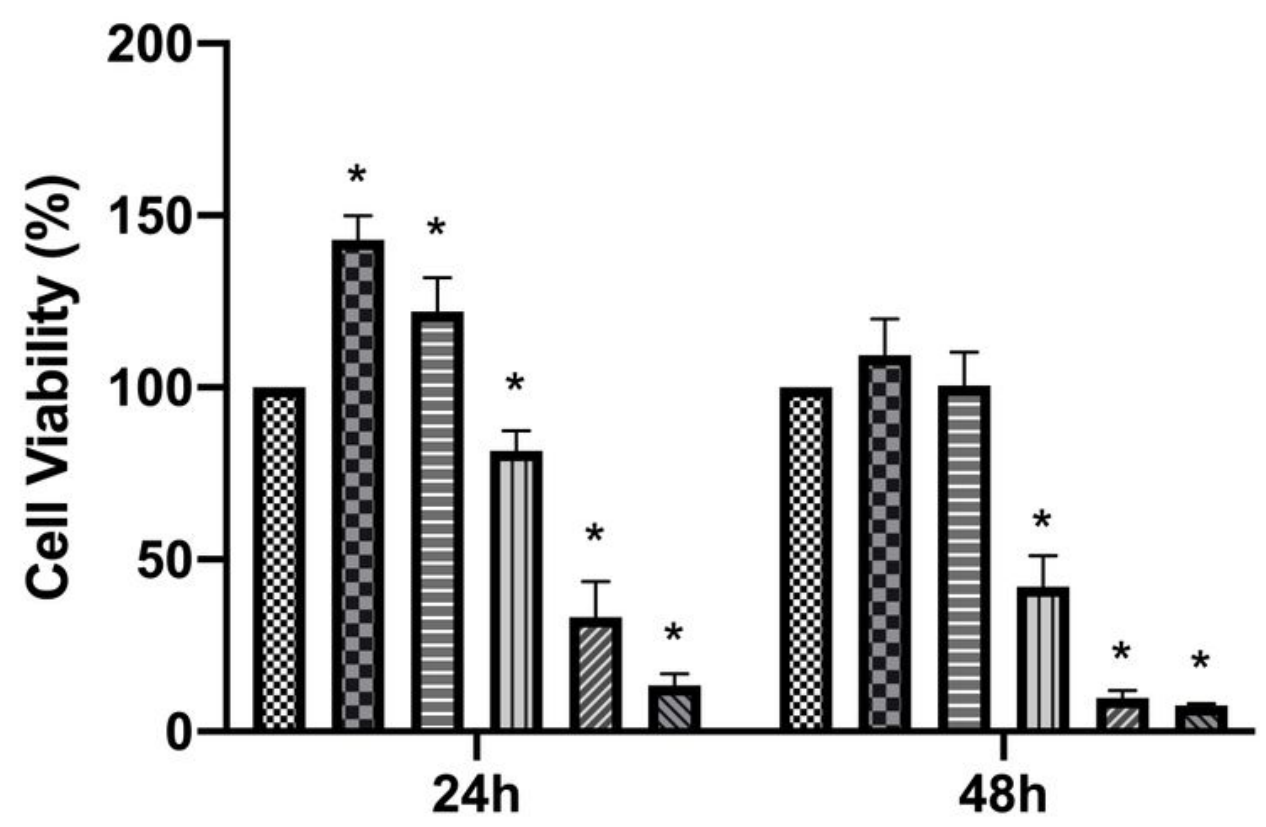

m Control

을 $6.25 \mu \mathrm{M}$ ErPC3

曰 $12.5 \mu \mathrm{M}$ ErPC3

III $25 \mu \mathrm{M}$ ErPC3

שू $50 \mu \mathrm{M}$ ErPC3

all $100 \mu \mathrm{M} \mathrm{ErPC3}$

Figure 1

The effects of different concentrations $(6.25-100 \mu \mathrm{M})$ of ErPC3 on the cell viability of A549 (A) and DMS 114 (B). $\left({ }^{*} p<0.05\right)$. 
Control

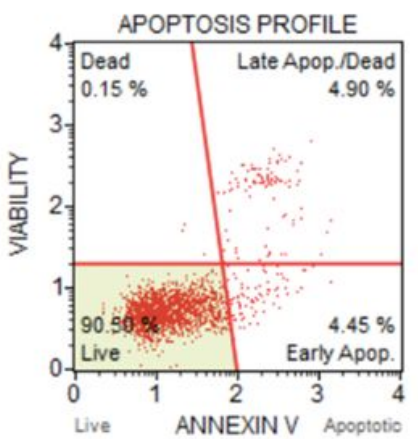

B

\section{Control}

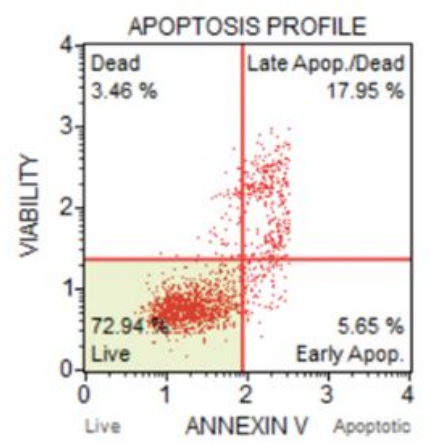

$25 \mu \mathrm{M}$ ErPC3

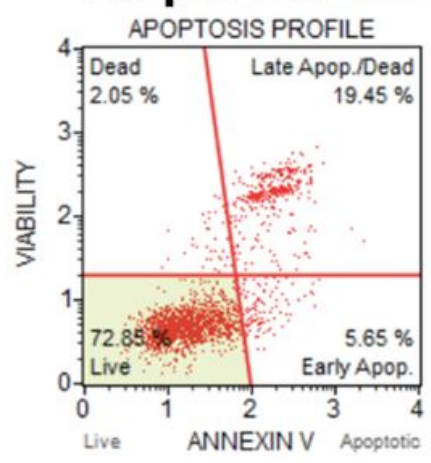

$25 \mu \mathrm{M}$ ErPC3

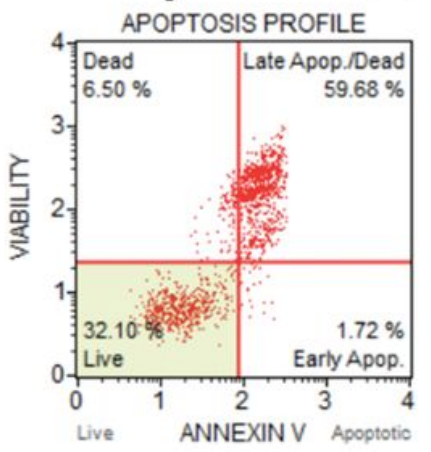

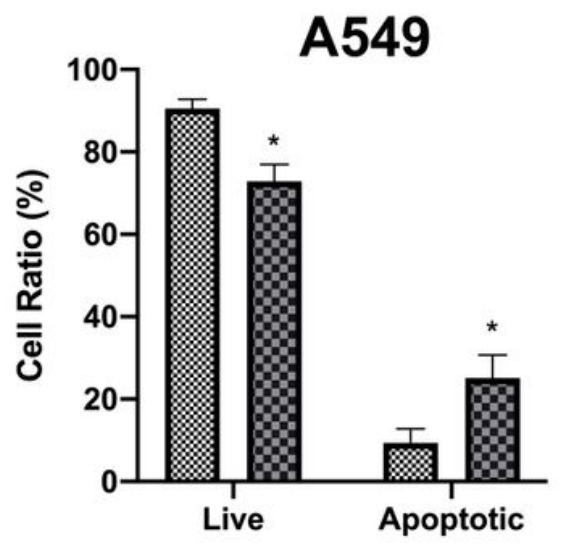

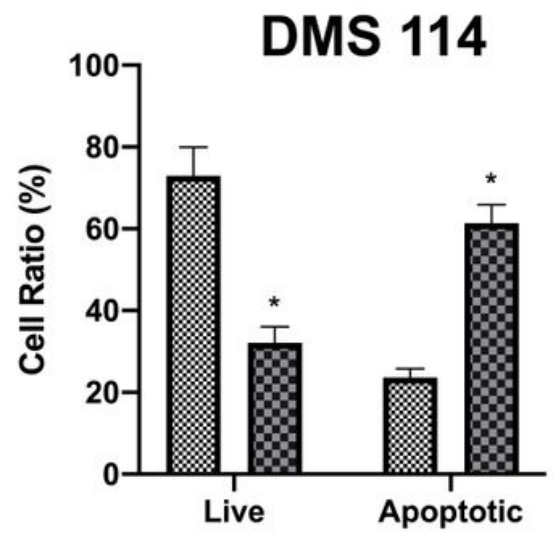

m Control

ख $25 \mu \mathrm{M}$ ErPC3
Control

$25 \mu \mathrm{M}$ ErPC3

\section{Figure 2}

The apoptotic situation of A549 (A) and DMS 114 (B) under $25 \mu \mathrm{M}$ ErPC3 treatment. The bars graph indicates the percentage of live and apoptotic cells. $\left({ }^{\star} p<0.05\right)$. 
A

Control

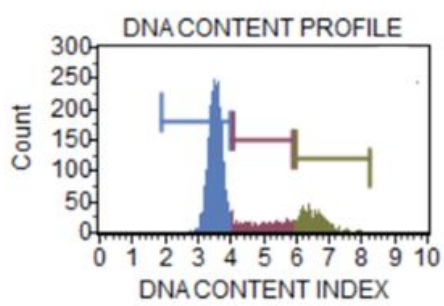

B

Control

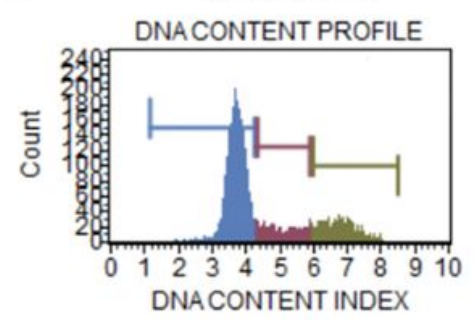

$25 \mu \mathrm{M}$ ErPC3
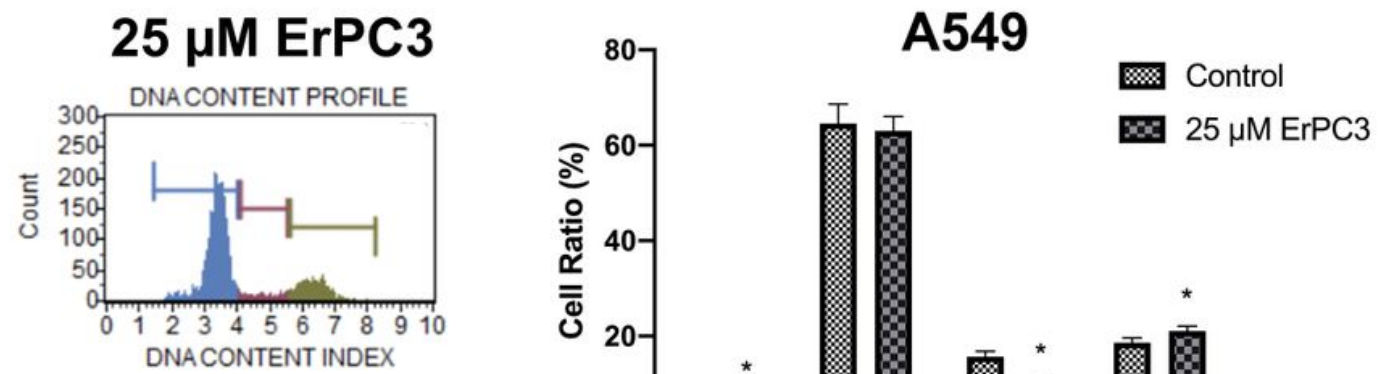
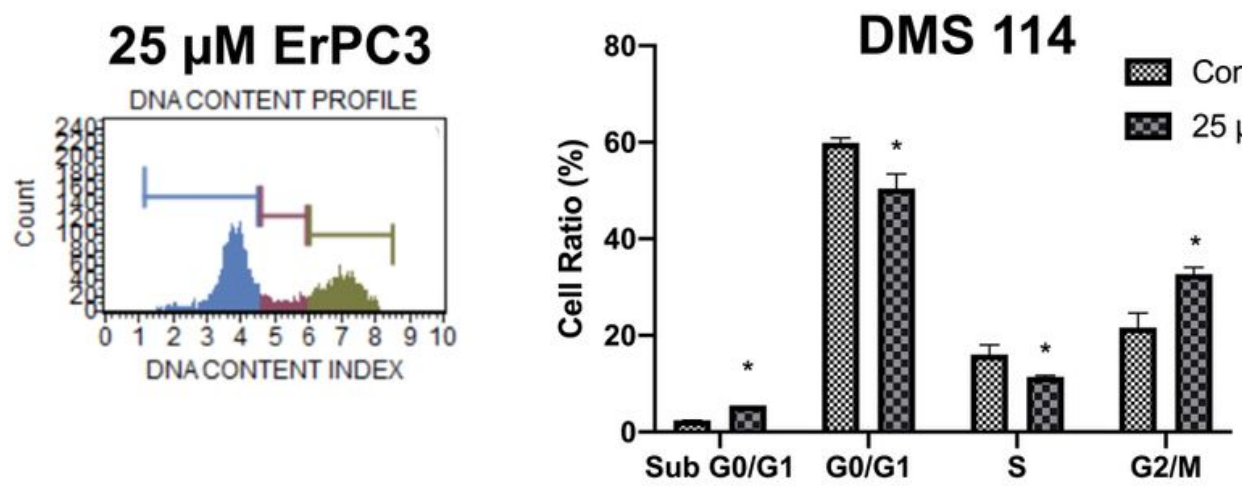

Figure 3

The cell cycle distribution of A549 (A) and DMS 114 (B) under $25 \mu \mathrm{M}$ ErPC3 treatment. The bars graph indicates the percentage of cell cycle phase distribution. $\left({ }^{*} p<0.05\right)$. 
A
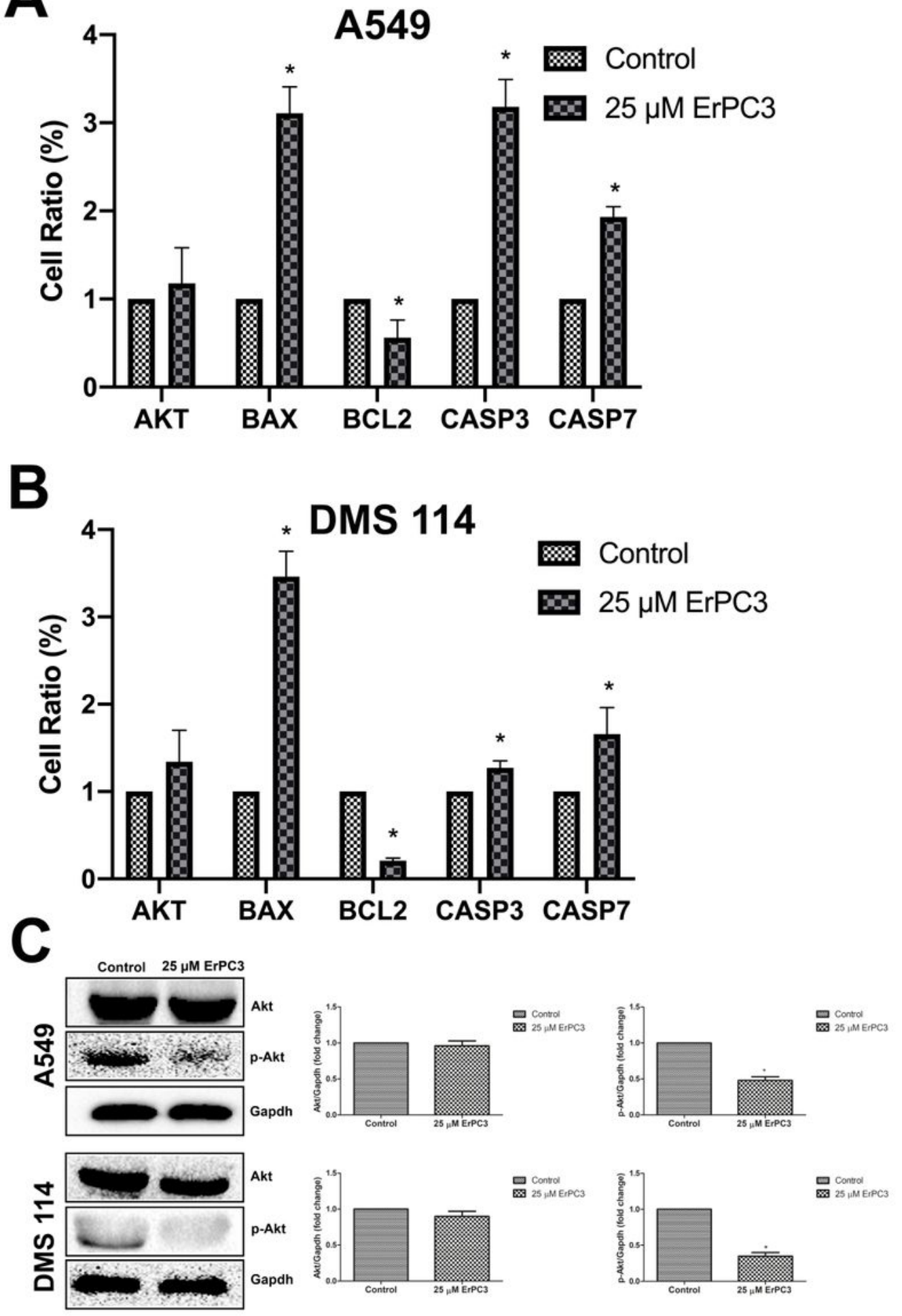

Figure 4

The effect of $25 \mu \mathrm{M}$ ErPC3 on the gene expression level of related genes in A549 (A) and DMS 114 (B) after $48 \mathrm{~h}$ treatment. The effect of $25 \mu \mathrm{M}$ ErPC3 on the protein expression level of Akt and p-Akt in A549 and DMS 114 after $48 \mathrm{~h}$ treatment by western blot analysis $(\mathrm{C}) .\left({ }^{*} \mathrm{p}<0.05\right)$. 
A Control
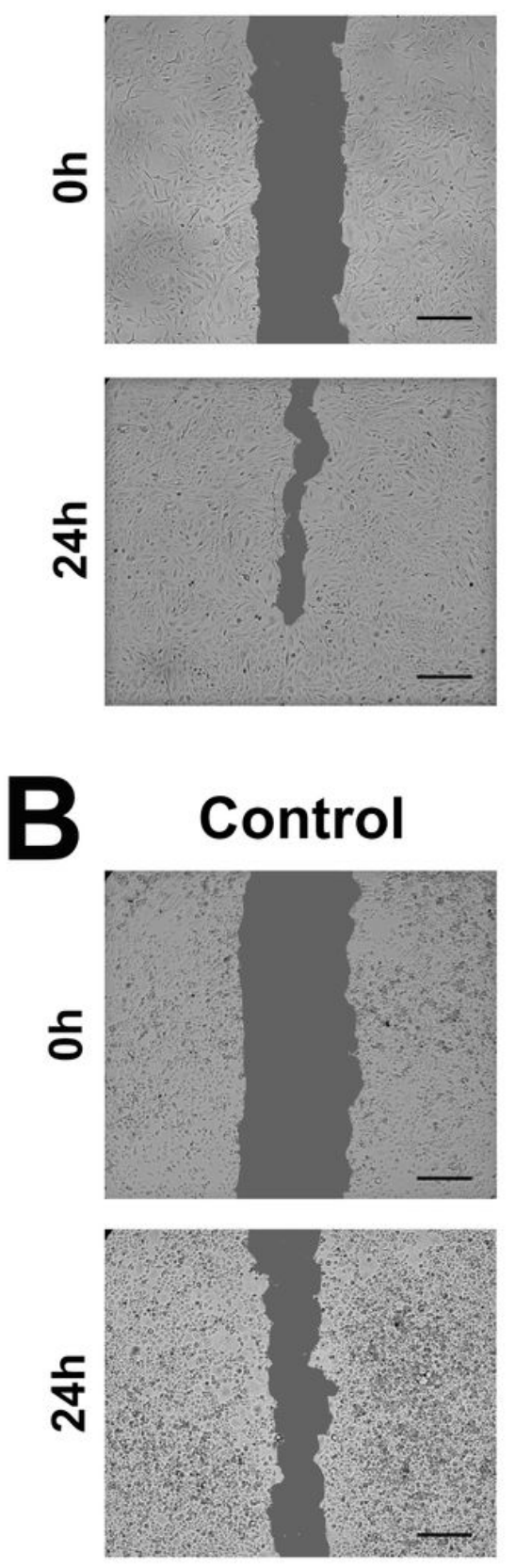

\section{$25 \mu \mathrm{M}$ ErPC3}
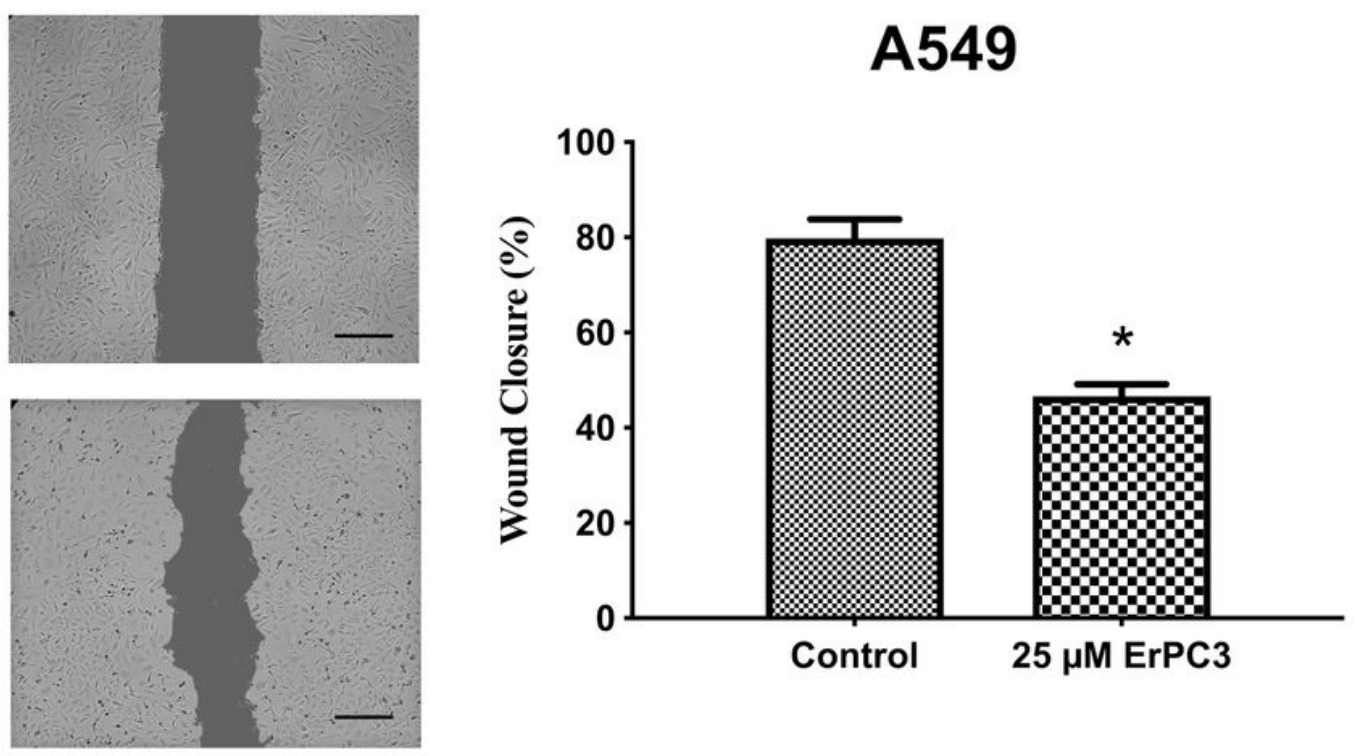

$25 \mu \mathrm{M}$ ErPC3
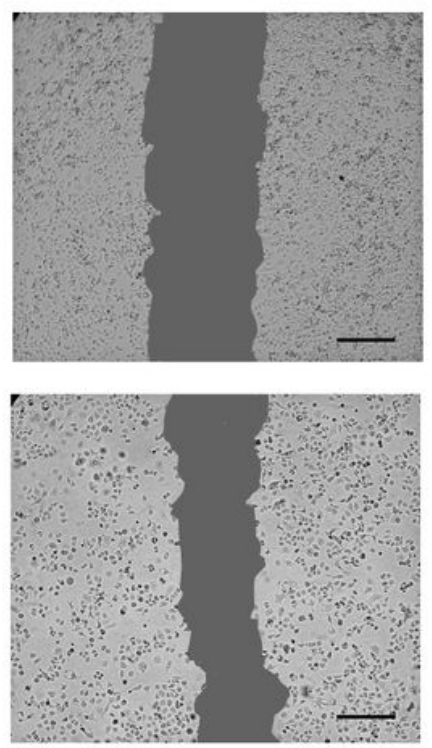

DMS 114

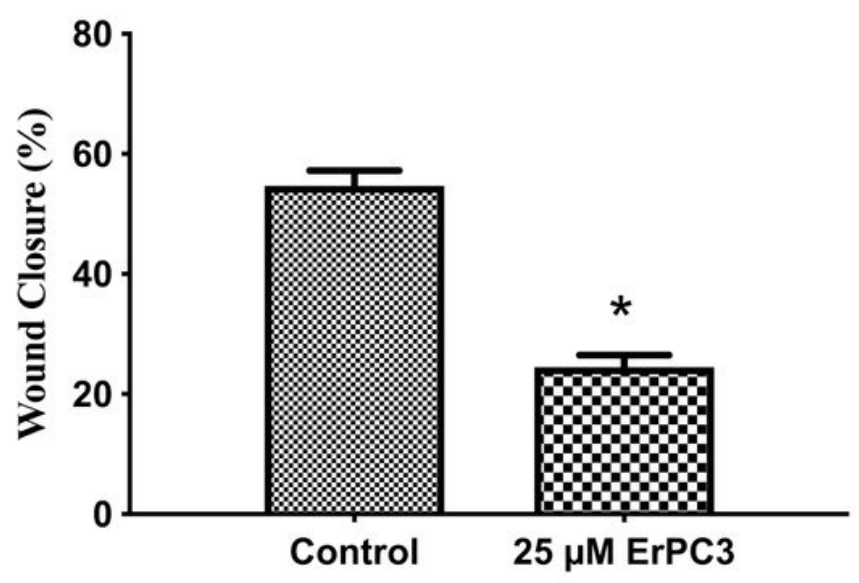

Figure 5

Scratch assay photographs of A549 (A) and DMS 114 (B) under $25 \mu \mathrm{M}$ ErPC3 treatment at $0 \mathrm{~h}$ and $24 \mathrm{~h}$. The bars graph indicates the percentage of wound closure. ( $\left.{ }^{\star} p<0.05\right)$, (Scale bar $\left.200 \mu \mathrm{m}\right)$. 